\title{
RECALLING THE FUTURE OF ACC
}

\author{
Richard Gaskins*
}

Richard Gaskins visited the Law Faculty as a Fulbright from January to August 1999 to study developments in the Accident Compensation regime. His visit coincided with the controversy surrounding the National Government's Accident Insurance Act 1998. Professor Gaskins gave the following paper, in which he addresses the continued importance of the Woodhouse Report, at a seminar on Accident Compensation held as part of the 1999 Australasian Law Teachers' Association Conference.

In the paper he highlights two important insights of the Woodhouse Report that he believes have lasting value: its linking of tort reform to social welfare and its promotion of an ecological approach to preventing accidents. Professor Gaskins concludes that both insights retain their importance and challenges legal academics to address them as well as the more narrowly based law and economic approach to accidents that has dominated legal policy and academic thought since the early 1970s.

This year marks the twenty-fifth anniversary of the accident compensation scheme (ACC) in New Zealand, but celebrations are somewhat muted. Within New Zealand, a debate is now taking shape over two very different futures for ACC, as projected by the leading political parties. The National Party passed a comprehensive new law in December 1998, the Accident Insurance Act (AIA), which carries ACC part way down the road to privatisation. The Labour Party, meanwhile, has vowed to repeal that law, should it win the next election, and to return to earlier principles, including a single public fund and new strategies for prevention and rehabilitation.

This paper speaks to some wider policy debates, both here and abroad, that touch on the New Zealand experience. The world took strong notice of ACC when the scheme began, and one of the first challenges for academics today is to reassess the historical

* Brandeis University, Massachusetts. This paper was presented at a seminar on ACC held in conjunction with the Australasian Law Teachers' Association in Wellington, New Zealand, 7 July 1999. The author wishes to thank Geoff McLay, John Miller, Bill Atkin, Don Rennie, Ian B Campbell, Ross Wilson, among other colleagues and officials for their assistance during the author's residence in New Zealand as a visiting scholar. Further thanks are due to the Fulbright commissions in both New Zealand and the United States for their generous support. The opinions in this paper remain the sole responsibility of the author. 
significance of that original vision, including its impact on other countries. A second task for academic inquiry is to interpret the ups and downs of ACC's eventful life, through all the vagaries of implementation. We already have Ian Campbell's fine study, but more such work will be needed. A third task should look to the future, to speculate on new directions in compensation policy in light of the New Zealand experience. My comments are restricted to the first and third tasks, and thus deal with both the historical and future significance of ACC.

I shall focus on the Royal Commission on Personal Injury, which reported in December 1967 under the chairmanship of Sir Owen Woodhouse. ${ }^{1}$ The Woodhouse Report and its much-reproduced five principles have become something of a mantra in later discussions, at risk of becoming a rhetorical rag-bag for quite opposing views. There are essentially three ways to regard the Woodhouse Report at this point in history. First, the Report had little to offer back in 1967, and we should start over with policies based on current needs. Second, the Report actually did have something useful to say back then; but those were warm and fuzzy days, and it is time to pass on to something more contemporary. And third, the Report actually said something profound and prophetic, creative in its own day, but also useful in future policy development.

This paper explains briefly why I think the third position is correct. It concludes that the Woodhouse scheme belongs at the forefront of future policy debates, and that it contains certain valuable insights that have not been fully appreciated, both in New Zealand and abroad. I shall combine my observations on past and future by focusing on two central ideas in the Woodhouse conceptual universe. Although I begin by placing these ideas in their historical context, I believe that their future importance cannot simply be presumed, but rather needs to be restated in contemporary terms.

The first of these central ideas speaks to the relationship between civil liability law, as Woodhouse found it in 1967, and the social welfare philosophies of his day. This relationship between law and social welfare is vital, but has gotten lost in the past 25 years as ACC has settled into its unique bureaucratic niche. The Woodhouse Report integrates personal-injury law with social welfare principles, paying attention to both sides of the equation. On the one side, Woodhouse measured outcomes of the common law regime by using substantive standards of social welfare, not the conventional formal standards internal to the judicial process. On the other side, and more dramatically, he borrowed

1 Report of the Royal Commission of Inquiry Compensation for Personal Injury in New Zealand (Government Printer, Wellington, 1967) [Woodhouse Report]. 
common-law notions to create new definitions of social welfare. This complex, two-way argument needs to be understood from both sides of the relationship. ${ }^{2}$

The first part of the argument is not original with Woodhouse. It says that personalinjury law is not an end in itself, but should serve larger goals of public benefit. Even when the legal process shows perfect formal consistency and propriety, it must be measured by extrinsic goals of public policy. From this perspective, personal-injury law fails to deliver "comprehensive entitlement," one of the five Woodhouse principles. Using various welfare standards, this functional perspective goes back through the history of tort law commentary, all the way back to Holmes on the American side. By the 1960s the standards of modern welfare states were invoked to challenge the operation of tort law as a compensation system, notably by the Oxford scholar (and New Zealander) Donald Harris $^{3}$ and by Canadian professor Terence Ison. ${ }^{4}$ Ison's book-length indictment of the "forensic lottery" works out the fine details of this critique. Even Guido Calabresi echoed the received wisdom in his landmark book. ${ }^{5}$ To be sure, definitions of "welfare" remained diverse during this period, but welfare-instrumentalism of some variety was standard fare. Perhaps the only American tort commentator to dissent was the young Richard Epstein, who built his first doctrinal arguments on a libertarian blend of moral intuition and natural law. ${ }^{6}$

The Woodhouse Report was more original in its reverse argument, which expanded the meaning of public welfare by importing common law notions of responsibility. It is worth recalling that the Woodhouse Report appeared when another Royal Commission was being formed to review benefits under social security and health programmes. The basic criteria of public welfare in New Zealand were not only different from those used by most American tort scholars, but were themselves in a state of flux. The Woodhouse Report made one of its most daring contributions in arguing for earnings-related benefits in a public welfare scheme, invoking common-law standards of entitlement under the Woodhouse rubric of "real compensation." These deliberations on welfare seem long distant now, given the revolution in social policy that swept through Thatcher's Britain, Reagan's America, and Douglas' New Zealand in the 1980s. Alongside its other purposes,

2 These paragraphs draw on earlier views developed by the author in collaboration with other colleagues, whose contributions he gratefully acknowledges. See Richard Gaskins, Jane C Kronick and William W Vosburgh "Community Responsibility for Accident Victims: Changes in the New Zealand Welfare State" (1979) Social Science Review 51, 261-274.

3 Donald Harris "The Law of Torts and the Welfare State" [1963] NZLJ 171-181.

4 Terrence Ison The Forensic Lottery (Staples Press, London, 1967).

5 See Guido Calabresi The Costs of Accidents (Yale University Press, New Haven, 1970) 43.

6 See Richard Epstein "A Theory of Strict Liability" (1973) 2 J Legal Stud 151. 
the Woodhouse Report was advancing a new standard of public entitlement. In the context of personal injury compensation, welfare and distributive justice were said to be mutually reinforcing. Perhaps the same principle could extend to other parts of social welfare?

The social policy side of the equation was not fully developed in the Woodhouse Report, but the 1972 Report of the Royal Commission on Social Security ${ }^{7}$ lays it out for discussion. That Report ponders three competing welfare criteria aimed at different levels of support for recipients: offering them basic subsistence, preserving their capacity for social participation; and maintaining their achieved economic status. Using the field of personal-injury compensation as its paradigm case, the Woodhouse scheme was one of the first proposals anywhere in the world for the third type of public entitlement. Woodhouse borrowed from common-law justice to import this ideal into the field of accident compensation, but from there it was open to further expansion on principles of general equity. Had it occurred, such expansion would have fulfilled the dynamic model projected by the English welfare theorist, Richard Titmuss, ${ }^{8}$ itself based on the evolutionary arguments of T H Marshall on social citizenship. Although history did not work out this way, Titmuss had predicted that the welfare states of Western Europe would reach a point of economic development where they could secure the economic independence of all citizens. Earnings-related benefits were the goal. The New Zealand ACC gained international attention for building this new approach into legislation. A clever judge had transplanted a social welfare principle into common-law soil.

The tension between compensation for accidents and compensation for illness needs to be seen in this light. The Woodhouse Report announced the broader logic of its new standard: welfare justice for accident compensation should be extended to incapacity from any source, including disease. ${ }^{9}$ The Report left it to pending reviews of health and social security to expand these entitlement principles, once Woodhouse had firmly anchored them in common-law notions of real compensation. And, indeed, the Royal Commission on Social Security tentatively endorsed the Woodhouse standard for sickness benefits - but not for other welfare entitlements, opting instead for the middle standard of social

7 Report of the Royal Commission of Inquiry Social Security in New Zealand (Government Printer, Wellington, 1972) [Social Security in New Zealand].

8 See Richard Titmuss "Developing Social Policy in Conditions of Rapid Change" in Brian AbelSmith and Kay Titmuss (eds) The Philosophy of Welfare: Selected Writings of Richard M Titmuss (Allen \& Unwin, London, 1987) 254-268.

9 Woodhouse later expanded this argument into a legislative model for Australia. See the Report of the National Committee of Inquiry into Compensation and Rehabilitation in Australia (1974). 
participation. ${ }^{10}$ In the evolutionary context of the time, nonetheless, the 1972 Report was still travelling in the same direction, down the trail blazed by Woodhouse.

The Woodhouse Report was an ingenious concoction of traditional jurisprudence and evolving welfare principles. But now, three decades later, that vision seems eclipsed by events. The Woodhouse-ACC era belongs on the other side of that great economic and ideological divide, marked by two big oil-shocks of the 1970s and the rise of monetarism and other anti-statist movements. Today, for many policy analysts and academics, everything on the far side of that divide is ancient history; we have put the welfare state behind us. Does this mean the Woodhouse principles are hopelessly archaic?

This is not my own conclusion. We turn to history to understand the present, and not simply to feel superior to experiments of the past. Current prescriptions for ACC are themselves based on social welfare criteria that are annoyingly vague and imprecise, often tacitly drawn from the standards of microeconomic efficiency. It is far easier to dismiss the past than to defend these newer visions of public good. Ideas about social welfare today are just as fluid and contested as they were in the days of Woodhouse, but long-term assumptions have changed dramatically. In New Zealand this shift is now deeply embedded: privatising state institutions and trusting markets to produce better results are regarded by many as the inevitable course of progress. In this new evolutionary framework, shrinking the public sector occupies somewhat the same status today that Titmuss' confident welfare expansion occupied in the 1960s. Whether you embrace this change or abhor it, the fact remains that concepts of public welfare still shape ACC legislation, up to the present day. They may hide behind the analytic models of microeconomists, but their power can be detected in the descending benefit structures that accompanied ACC reforms in the 1990s. No doubt different welfare definitions are present in the Labour Party's alternative model, which rejects the trend toward lower safety-nets. To be sure, earnings-related benefits from the Woodhouse era have lost their original significance, especially given the greater disparities of incomes today in New Zealand, as opposed to 1967. But standards of public entitlement must still be defined, and basic subsistence is only one option among several.

The Woodhouse Report was singular in the degree to which it explained its distinctive welfare vision. To say this is not necessarily to endorse a return to the welfare state of the 1960s, but rather to push today's debates on accident compensation to a deeper level: to reach their foundations in contestable definitions of public good. Moving to this level is especially urgent for the accident compensation debate in New Zealand, but it is also important for ongoing debates about tort reform, workers' compensation and civil liability

10 See Social Security in New Zealand above n 7, chapter 18. 
systems throughout the developed world. Academic commentators can supply this missing dimension, inspired perhaps by the boldness of Woodhouse's example.

However, there is still more to be said about the Woodhouse Report, besides commending its clear reflection on social norms. I mentioned earlier that I would explore two major issues, one of which was this reciprocal connection between social welfare and common law. While this complex idea is important and often overlooked in published summaries of the Woodhouse era, it concentrates more on values beyond the physical reality of accidents. Missing from this formula is a powerful companion theme that runs throughout the Woodhouse Report, traveling under the mysterious phrase "community responsibility." This term is frequently dismissed as idle rhetoric and it risks becoming almost meaningless by casual repetition in New Zealand debates. To me, it has always offered the key to unlocking the Woodhouse legacy. Above all, it warns against one of the tragic failures of the New Zealand ACC in practice: the failure to address accident prevention in a comprehensive fashion.

Time permits only a brief explanation of this last but most central part of the Woodhouse message, which defines "accidents" in a new way. Let me paraphrase it as follows. Accidents are complex human events, involving multiple lines of responsibility. All events - including accidental events - are overdetermined by multiple causes, guided by multiple agents. This message is not some descent into chaos theory, but a dose of sociological realism supported by a long tradition of progressive social analysis. ${ }^{11}$ Strictly personal choices are not the ultimate building blocks of the universe, but are always socially embedded. Collective action is more than the sum of its parts. It follows that responsibility for accidents is not completely reduced to private individuals and their discrete choices, but assumes parallel lines of responsibility for groups, networks, organisations, corporations and government agencies. These agents, in turn, act upon each other through a matrix of structures, forces and systems; some of which they only dimly understand. Human beings can control their environment, but not entirely. Their success depends on social co-ordination, not just assertions of personal choices.

People have begun to recognise that the accidents regularly befalling large numbers of their fellow citizens are due not so much to human error as to the complicated and uneasy environment which everybody tolerates for its apparent advantages. The risks are the risks of social progress, and if there are instinctive feelings at work today in this general

11 A representative figure in American progressivism is John Dewey. See, for example, The Public and Its Problems (Holt, New York, 1927). 
area they are not concerned with the greater or lesser faults of individuals, but with the wider responsibility of the whole community. ${ }^{12}$

Just because Woodhouse says it does not mean it is true, of course. In 1967 there was possibly little recognition of where this rather dense concept might lead. Community responsibility was a malleable phrase within the Woodhouse Report. For some readers, it meant simply that the accident scheme should be funded by a wide range of contributors. At times it seemed to play with metaphysical abstractions, projecting some brooding societal agent as vicariously responsible for all the accidents that happen, no matter how private or personal they may seem. Thirty years later, however, I think we can explain this concept better as an ecological perspective on accidents. Human ecology was a young discipline at mid-century and by the 1960s it was applied to environmental degradation in books like Rachel Carson's Silent Spring. ${ }^{13}$ Epidemiological science and its universe of risk factors matured during the 1960s as a corollary of these trends. I am not saying that the environmental movement influenced Woodhouse directly, the way Terry Ison's book obviously did. I think rather that Woodhouse discovered for himself the equivalent ecological relations at work in modern industrial accidents, much as Durkheim found them by studying social relations at the turn of the last century. Finally, please note that this perspective applies equally to chronic disease and traumatic injury. Indeed, it absorbs personal injuries into a public health framework. ${ }^{14}$

This is not the occasion to push this interpretation much further. Instead let me apply it to one highly contentious issue in the current New Zealand debate: the problem of accident prevention. If the Woodhouse philosophy of social welfare strikes you as dated, his ecological theory of accidents may seem rather far ahead of its time. By comparison with the welfare-economic theory of accident deterrence, which still dominates the writings of most legal academics and policy analysts, the Woodhouse principle is closer in spirit to different injury prevention methods that are now in the ascendancy. And finally, at the end of the day, the ecological theory of accidents provides entirely new reasons to revisit the Woodhouse welfare philosophy, which should not be counted as entirely dead.

Briefly, then, let me return through history and take you back to the 1970s, after the Woodhouse Report had been transformed into the early ACC. Despite their concurrence on the limits of common law as a compensation system, up-and-coming tort theorists

12 Woodhouse Report above n 1, s 89.

13 Rachel Carson Silent Spring (Hamish Hamilton, London, 1963).

14 For the emergence of environmental health concerns out of the pre-WWII industrial hygiene movement, see Christopher C Sellers Hazards of the Job: From Industrial Disease to Environmental Health Science (University of North Carolina Press, Chapel Hill, 1997). 
around 1970 were poised to diverge from the Woodhouse approach. They found a new social function for common law in the field of accident prevention. It soon became fashionable among international (as well as New Zealand) commentators to dismiss the Woodhouse project as naïve and unlettered for failing to acknowledge this trend toward deterrence-based prevention. The New Zealand Business Roundtable (NZBRT) considers this omission in Woodhouse a massive "non sequitur," although the NZBRT's own vision prefers private contracts to tort in pursuit of deterrence. ${ }^{15}$ I must admit, for my part, that I share the quite different view expressed in 1980 by the Israeli legal scholar Izhak Englard, who described this whole shift to deterrence theory in torts scholarship as "...a desperate scholarly rearguard action to preserve a traditional system of individualism in a changing world....". 16

My time permits me only to assert, without any real defence, that the Calabresi-Posner turn to accident deterrence was a costly diversion from the richer possibilities contained in the Woodhouse Report. Calabresi made a brilliant contribution to analytic theory by applying new formal concepts in welfare economics to a small, time-bound question within tort law: the choice between doctrines of strict liability and negligence in the new field of product liability. Posner answered him in 1972 on this limited topic, importing still further neo-classical assumptions about human behaviour from his Chicago School colleagues. The full-blown theory of accident deterrence then emerged the way many academic fashions develop, as a scholastic exercise in formal modeling, exploiting all the intellectual rigor of economic theory-building. In historical terms, this academic trend soon dovetailed with a major ideological shift in public policy in the 1980s, away from state-building policies and toward market systems as the new guardians of public welfare. What neo-liberal policy analysts liked about the Calabresi-Posner movement was the theory of deterrence through market-style signals. Indeed, tort law became a baroque afterthought, and in America most deterrence theorists want to trim tort doctrines severely to match their deeper image of ideal markets. Tort law as an independent force, let alone its sense of justice, drops out of the equation, to the extent it is not instrumental toward achieving market goals.

New Zealand, of course, is the one place on earth where personal injury law has already dropped out entirely, although for reasons quite different from those advocated by the NZBRT and others. When Woodhouse recommended an end to personal injury

15 See, for example, Roger Kerr Accident Compensation in New Zealand: A Proposal for Reform (New Zealand Business Round Table, Wellington, 1990); Richard Epstein Accident Compensation: The Faulty Basis of No-Fault (New Zealand Business Round Table, Wellington, 1996).

16 Izhat Englard "The System Builders: A Critical Appraisal of Modern American Tort Theory" (1980) 9 J Legal Stud 68. 
lawsuits, he did not envision a world without deterrence. His scheme left clear space for a comprehensive accident prevention strategy that is still waiting to be discovered and implemented. Rather than calling it "deterrence", which preserves a musty Benthamite vocabulary, I believe we should follow Woodhouse and imagine a broader public policy of injury "prevention."

Prevention is broader than deterrence because it includes a range of strategies beyond manipulation of personal motives through monetary rewards. It also requires careful attention to environmental design, public education, group interaction, organisational cultures and political coordination. Any modern policy of accident prevention that does not consider these strategies will miss the important health and safety challenges of the coming century. During the years that legal scholars have perfected their models of optimal deterrence, a very different literature has developed using ecological models of injury prevention, resting on established public health principles. ${ }^{17}$ That literature speaks to the challenge laid down by the Woodhouse Report when it made accident prevention its top priority, calling for a comprehensive and coordinated response to health and safety risks. This coordinated response is certainly one of the key meanings of "community responsibility".

The current ACC policy debate in New Zealand highlights these two competing approaches to accident prevention. On the one hand, the National Party's 1998 Accident Insurance Act advances the market-deterrence strategy, relying on insurance premiums set by private contracts. On the other hand, the Labour Party's proposed model borrows more from the ecological perspective, which subordinates market incentives to risk-reduction practices. Assuming that competition is always a good thing, it is time these two visions were encouraged to compete head-on in the academic literature, as well as in the policy arena.

In conclusion, let me suggest a broader coherence between the Woodhouse approach to injury prevention and his distinctive views on public welfare. Remember, Woodhouse, made distributive justice into a structural element of social welfare. Both in 1967 and today, personal injuries indicate losses that have already occurred; a random but statistically necessary part of our society has lost something through personal injury, and social justice requires some coordinated response. You cannot disguise the distributive nature of this analysis, nor its striking legal sense of obligation. Public welfare must

17 In addition to the classic article by William Haddon, Jr "Advances in the Epidemiology of Injuries as a Basis for Public Policy" (1980) Public Health Reports 95, 418, see Peter Barss Injury Prevention: An International Perspective (Oxford University Press, New York, 1998); Charles Perrow Normal Accidents (2 ed, Princeton University Press, Princeton, 1999); Niklas Luhmann Risk: A Sociological Theory (Aldine de Gruyter, Berlin, 1993). 
address distribution as a matter of justice, redeeming the old common-law ideals of real compensation and comprehensive entitlement. In today's public welfare philosophies, the commitment to distributive justice is largely missing; it finds no easy place within the scope of efficiency-driven economics. For many, the cost of ACC is simply a net burden to the public purse, and funding ACC is like any other budget decision - purchasing a new frigate, or indeed cutting taxes. According to the Woodhouse model, however, the costs of injury belong in some different calculation. These costs have already been paid by some members of society, and the question is whether to leave them randomly assigned or to distribute them according to a principle of equity.

Let me conclude with that puzzle. If you wrestle with it, I think you will realise what Woodhouse was trying to say about social welfare back in 1967. Today we might select a different standard of benefits than what Woodhouse suggested, but it is hard to reject his basic argument that justice demands a co-ordinated social response to personal injury. Alongside his theory of prevention, these important welfare notions belong in the policy debates of future decades. 
